\author{
Gabriel MARKOVIČ ${ }^{1}$ \\ Zuzana VRANAYOVÁ2 \\ Daniela KAPOSZTÁSOVÁ
}

\title{
RESEARCH AND EVALUATION OF INFILTRATION SHAFT EFFICIENCY IN REAL CONDITIONS
}

\begin{abstract}
Infiltration of rainwater runoff as a disposal method of rainwater runoff, become an integral part of rainwater management. Infiltration of water from surface runoff has over conventional disposal of rainwater, i.e. draining into the sewer system and next to surface water a number of benefits especially from the environmental, technical and economic point of view. Infiltration facility is a device designed for fluent and natural infiltration of rainwater incoming from the roofs of buildings and paved surfaces into the underground space. The basic principle and function of all types of infiltration systems and facilities as quickly as possible to drain rainwater into the underground space and there it with a time delay infiltrate into the surrounding soil.
\end{abstract}

Keywords: efficiency, infiltration, rainwater, runoff, shaft, soil

\section{Introduction}

There are numerous techniques and approaches known around the world how to support sustainable stormwater management, especially in the urban areas, where the stormwater can cause significant damages. Safe drainage of rainwater is a problem of almost every new building in an urban area and in area with undersized sewage systems in Slovakia too. Waste-water disposal systems, sewage treatment plants and recipients of water flows are overloaded and the risk of floods grows. This represents another reason for waterworks companies to have the possibility of forbidding the disposal of rainfall water from surface detention into the waste-water disposal system already during the creation

\footnotetext{
${ }^{1}$ Corresponding author: Gabriel Markovič, Institute of Architectural Engineering, Vysokoskolska 4, 04200 Kosice, Slovakia, + 00421556024143, gabriel.markovic@ @uke.sk

2 Zuzana Vranayová, Institute of Architectural Engineering, Vysokoskolska 4, 04200 Kosice, Slovakia, ++ 00421556024143, zuzana.vranayova@tuke.sk

3 Daniela Kaposztásová, Institute of Architectural Engineering, Vysokoskolska 4, 04200 Kosice, Slovakia, +00421556024143, daniela.ocipova@tuke.sk
} 
and fulfillment of the development plan. This leads to the necessity of using rainwater infiltration systems or capturing rainwater for further reuse.

\section{Main design principles of infiltration facilities}

Main technical solutions for infiltration facilities are:

- Surface infiltration

- Swale infiltration

- Swale - Trench infiltration

- Infiltration trench and pipe infiltration trench

- Shaft infiltration

- Basin infiltration

- Undergroud infiltration blocks.

A very important design parameter of infiltration facilities is to determine the infiltration coefficient $\mathrm{k}_{\mathrm{f}}$ in the interest area. Infiltration coefficient $\mathrm{k}_{\mathrm{f}}$ generally represents an efficiency of infiltration facilities, respectively infiltration capability of the soil to absorb inflow water.

Permeability of the infiltration zone is a main qualitative and quantitative requirement for rainwater infiltration. Permeability of loose rock depends primarily on the size and distribution of the particles and compactness, in soils is critical soil structure and water temperature and is given by the infiltration coefficient. Permeability of loose rock varies in general between $1.10^{-2}$ and $1.10^{-}$ ${ }^{10} \mathrm{~m} / \mathrm{s}$. The $\mathrm{k}_{\mathrm{f}}$ values apply to the process of infiltration water in the saturated zone. The range of values for the filtration coefficient for technical drainage ranges from $1.10^{-3}$ and $1.10^{-6} \mathrm{~m} / \mathrm{s}[3]$.

The $\mathrm{k}_{\mathrm{f}}$ values greater than $1.10^{-3} \mathrm{~m} / \mathrm{s}$ cannot be reached for rainwater runoff and low depth of groundwater level the sufficient pretreatment through chemical and biological processes. If the $\mathrm{k}_{\mathrm{f}}$ values are smaller than $1.10^{-6} \mathrm{~m} / \mathrm{s}$, the percolation facilities are loaded very long time. For this reason, anaerobic processes in the unsaturated soil, which resulting in adverse effects on retention and capacity capabilities of the soil can occur.

Therefore, the most important design parameter of the infiltration facilities is to determine the filtration coefficient $\mathrm{k}_{\mathrm{f}}$ on-site. 


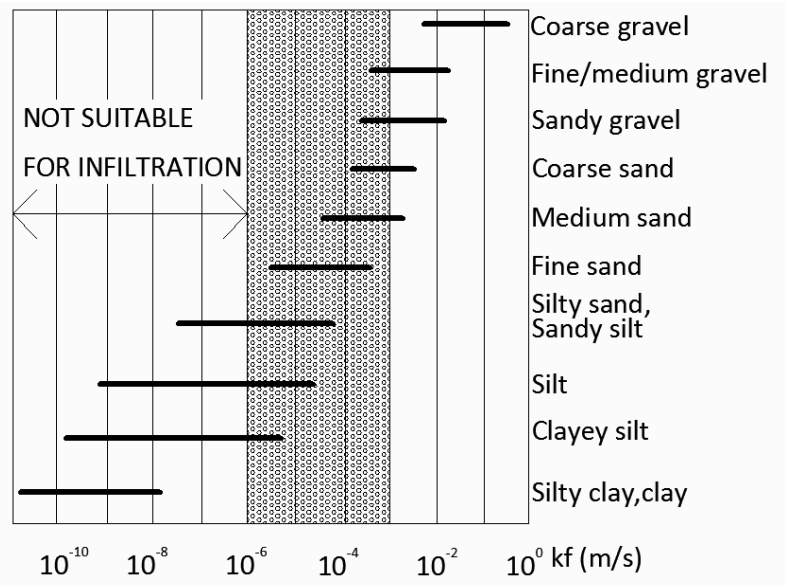

Fig.1. Recommended values of the infiltration coefficient [based on 1]

The infiltration facilities can't cause any damage to buildings or other facilities. Therefore, it always should be respected a minimum distance from buildings, basement of the buildings and the average amount of groundwater levels. These dimensions can vary from a few decimeters to several meters.

Figure 2 and 3 represent minimum distance from buildings. The same rules apply for underground infiltration facilities.

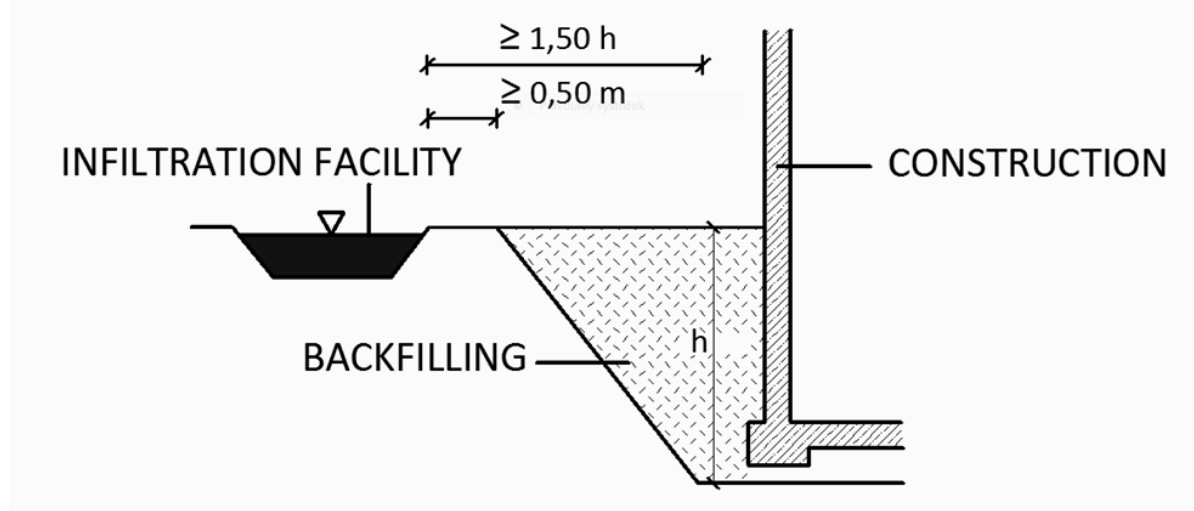

Fig. 2. The minimum distance of the decentralized infiltration facilities from building without waterproofing [based on 1] 


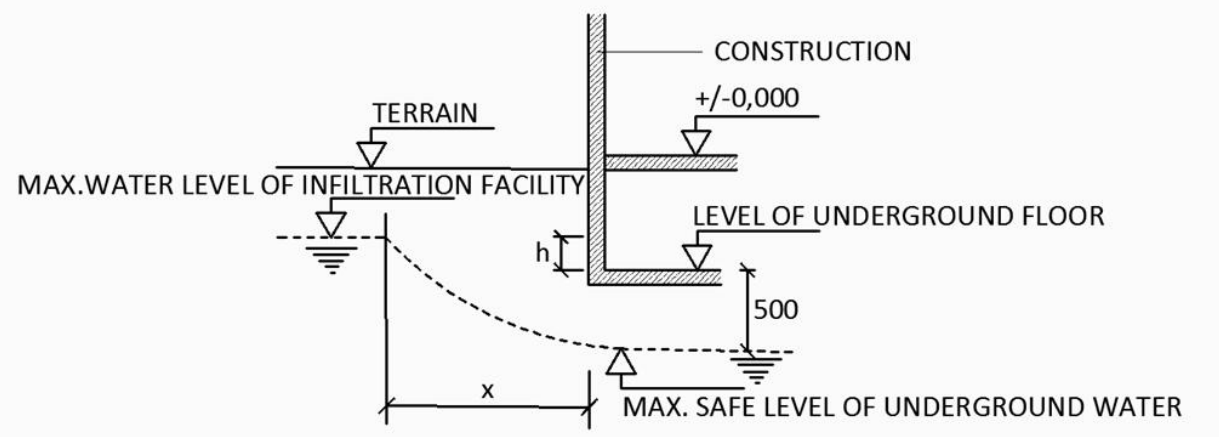

Fig. 3. Required separation distance from buildings [based on 4]

\section{Percolation shafts}

One of the types of infiltration facilities are percolation/infiltration shafts. It is a vertical underground infiltration facility which is usually made from concrete rings with the filter layer on the bottom (fig.4).

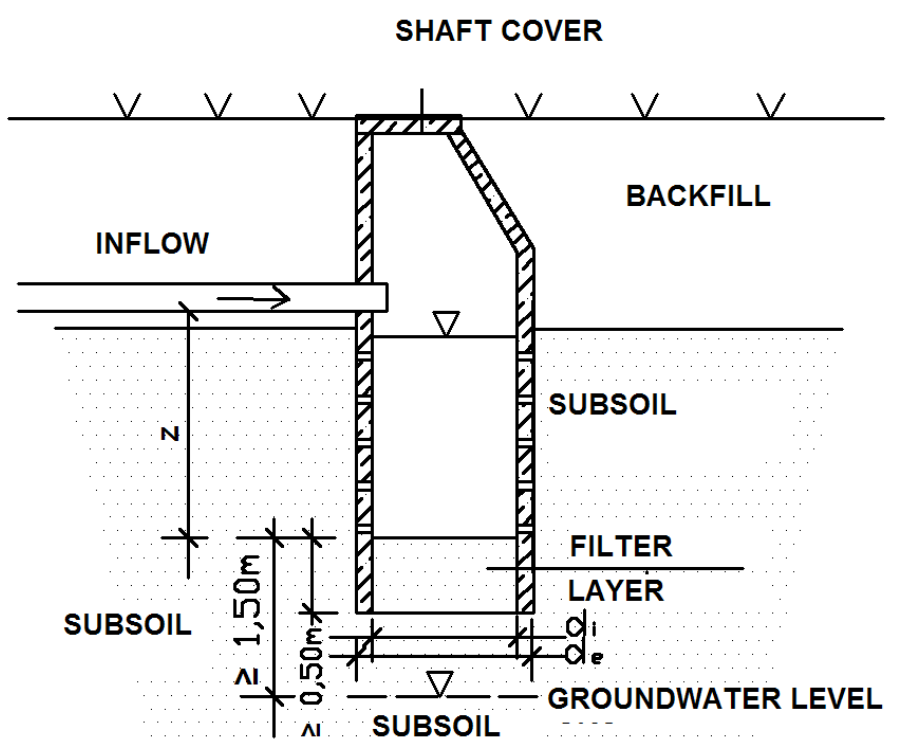

Fig. 4. Infiltration shaft

Rainwater from the catchment area is transported with system of vertical and horizontal rain pipes in underground space for infiltration. 
Infiltration shaft is a facility where the largest dimension is depth, so that design of this shaft depends of the highest water level in the shaft and also of the groundwater level in the interest area. The design of shafts must take into the account protection of groundwater and infiltration capability of shaft which is represents by infiltration coefficient on site [1] [2].

The design of shafts must take into the account protection of groundwater and infiltration capability of shaft. German standard DWA-A 138 indicates that it is necessary to place the bottom of the infiltration shaft a filter sack which is located above the filter layer. The total volume of inflow rainwater must pass through the filter sack before infiltration into the soil. The filter sack is absorbing all of the settle able and filterable solids and filter sack should be flushed or replaced [1]. Czech standard for infiltration indicates that on the bottom layer is placed layer of gravel at least $300 \mathrm{~mm}$. On this layer is placed geo-textile, which is recommended to protect with the gravel-sand layer [2].

\section{Measurements of quantity and quality of infiltrated rainwater - infiltration shaft efficiency}

The project APVV SUSPP-0007-09 relating to the management of rainwater, taking place at the Faculty of Civil Engineering in Košice, deal with research of infiltration shaft as one of the types of infiltration facilities. The research of rainwater infiltration takes place in infiltration shaft that were made before the start of the research and measurements. Both infiltration shafts are located by the PK6 building in campus of the Technical University of Kosice. All rainwater runoff from roof of this building is flow into the two infiltration shafts (Figure 5).

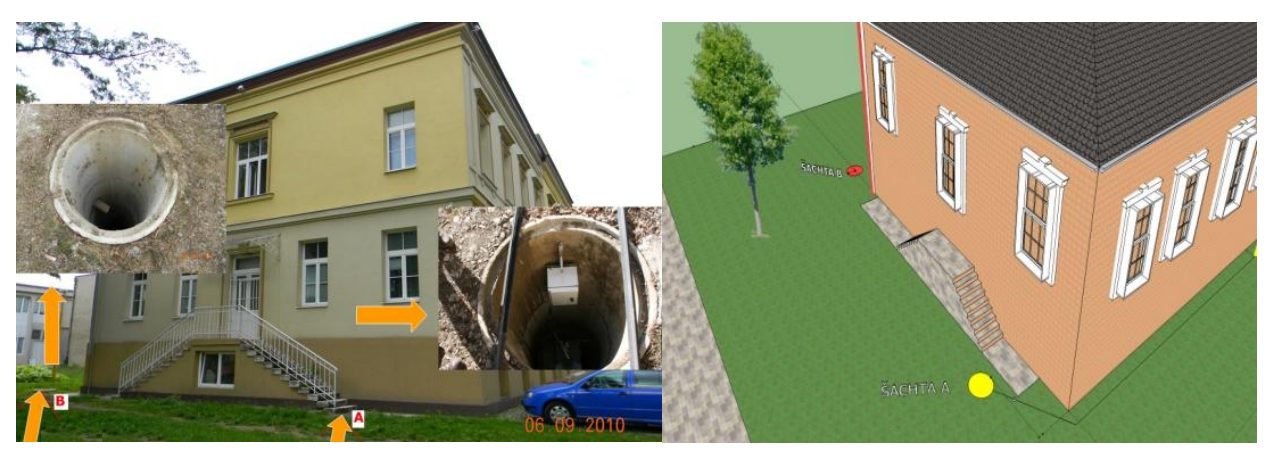

Fig. 5. Location of infiltration shafts near building PK6

It should be noted that the project of building drainage and project of design and realization of infiltration shafts is not available. All data, whether the pa- 
rameters of infiltration shafts or a drainage concept of rainwater from the building, were investigated on site (Figure 6).

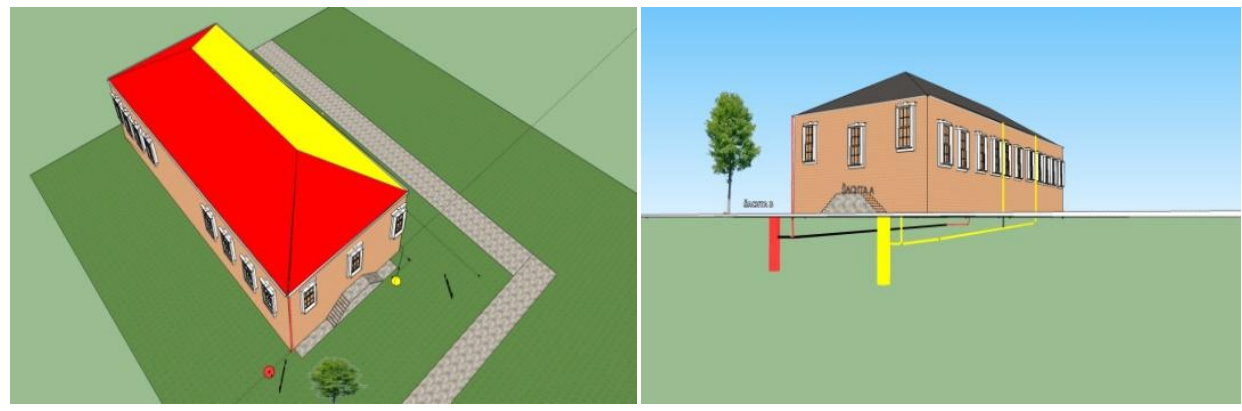

Fig. 6. Drainage of rainwater from roof of building PK6

Both infiltration shafts are located at the east side of the building PK6. The shafts are made from concrete rings with the outer diameter of $1000 \mathrm{~mm}$. Parameters of infiltration shafts are shown in Table 1.

Table 1. Parameters of infiltration shafts

\begin{tabular}{|c|c|c|}
\hline & SHAFT A & SHAFT B \\
\hline The outer diameter of shaft & $1000 \mathrm{~mm}$ & $1000 \mathrm{~mm}$ \\
\hline The inner diameter of shaft & $800 \mathrm{~mm}$ & $800 \mathrm{~mm}$ \\
\hline Shaft depth & $6,0 \mathrm{~m}$ & $5,9 \mathrm{~m}$ \\
\hline Depth of inflow & $1,65 \mathrm{~m}$ & $1,5 \mathrm{~m}$ \\
\hline DN of inflow pipe & $\mathrm{DN} 150$ & $1.10^{-3} \mathrm{~m} / \mathrm{s}$ \\
\hline $\begin{array}{c}\text { Infiltration coefficient at the } \\
\text { bottom }\end{array}$ & $1.10^{-3} \mathrm{~m} / \mathrm{s}$ & $336 \mathrm{~m}^{2}$ \\
\hline Drainage area of roof & $212 \mathrm{~m}^{2}$ & $2,18 \mathrm{~m}^{3}$ \\
\hline Accumulation volume & $2,11 \mathrm{~m}^{3}$ &
\end{tabular}

\subsection{Percolation performance of infiltration shaft in real conditions}

Infiltration coefficient $\mathrm{k}_{\mathrm{f}}$ of the soil in studied infiltration shafts near the PK6 building was made by taking samples of soil from the bottom of the infiltration shafts. Through the laboratory tests, the samples were evaluated as gravel blended with a fine-grained soil and infiltration coefficient set at $10^{-3} \mathrm{~m} / \mathrm{s}$.

Figures 7 and 8 represent 2 selected rainfall events from our research showing the process of inflow rainwater into the infiltration shaft and process of water level changing at the bottom of infiltration shaft A. The time for infiltration of rainwater at the bottom of shaft basically follows the process of precipitation, respectively inflow of rainwater into the shaft. Process of inflow rainwater into 
the infiltration shaft and process of water level change at the bottom of infiltration shaft $B$ is the same.
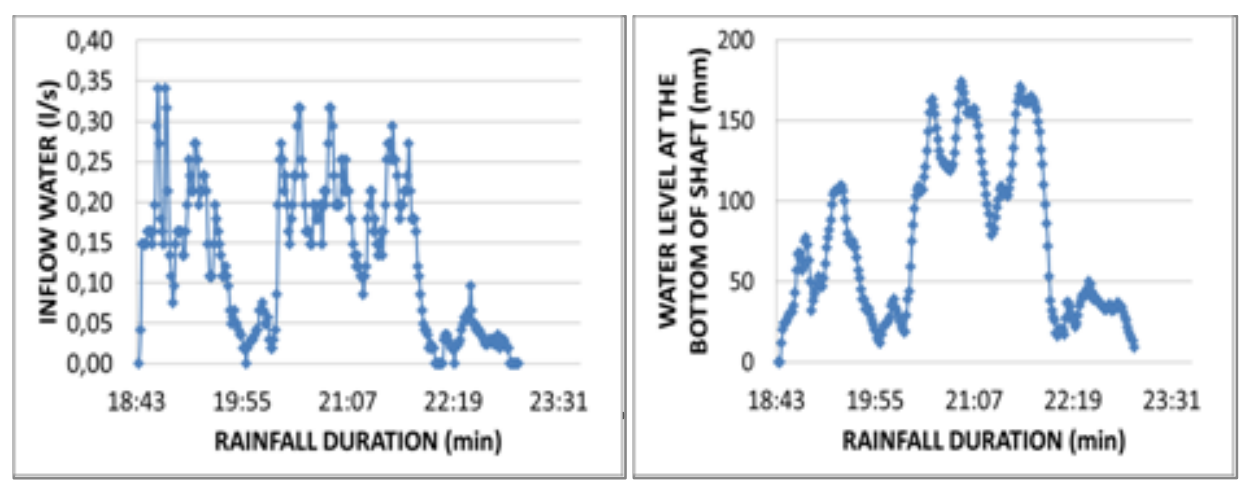

Fig.7. Volume of rainwater inflow and water level changes at the bottom of shaft during rainfall 7.10.2011[5]
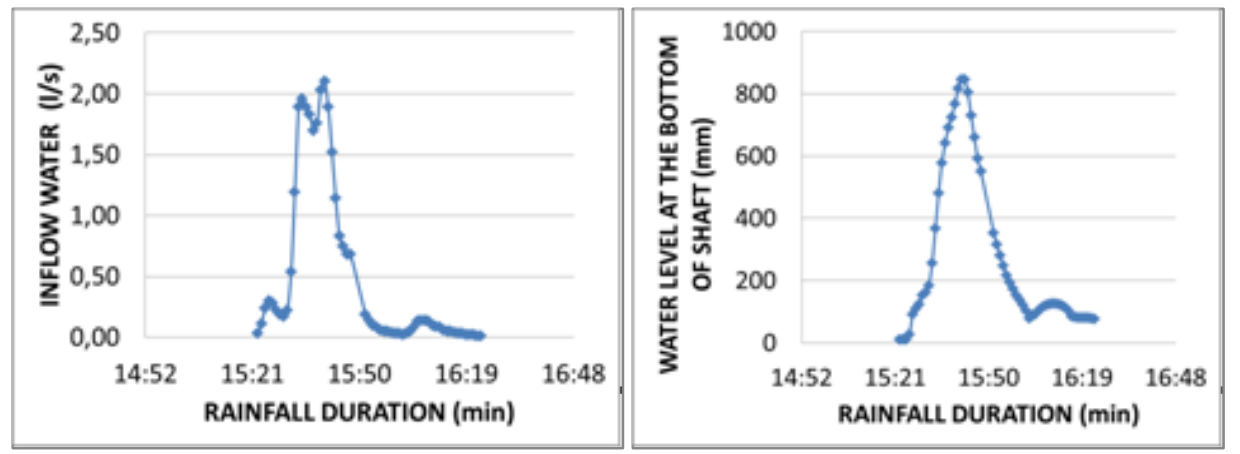

Fig.8. Volume of rainwater inflow and water level changes at the bottom of shaft during rainfall 1.9.2013

The maximum water level at the infiltration shaft $\mathrm{A}$, measured during the research period is $1,28 \mathrm{~m}$, which is less than $1 / 3$ filling depth of infiltration shaft A. Maximum water level at the infiltration shaft $\mathrm{B}$, measured during the research period is $1,31 \mathrm{~m}$, which is less than $1 / 3$ filling depth of infiltration shaft B too (figure 9,10). 


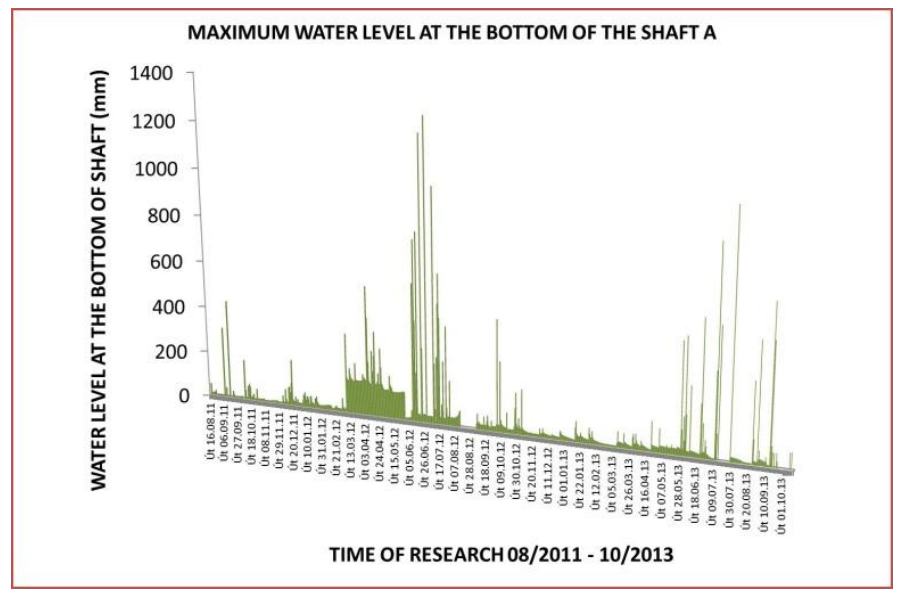

Fig. 9. Values of maximum water level at the bottom of the shaft A from August 2011 to October 2013 [5]

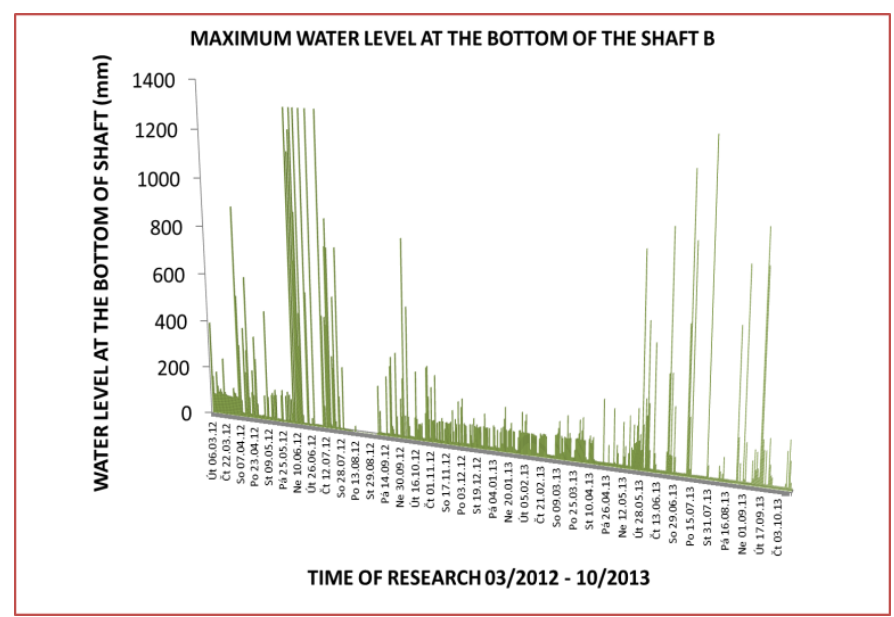

Fig.10. Values of maximum water level at the bottom of the shaft B from March 2012 to October 2013[5]

\subsection{Quality of infiltrated rainwater}

It is necessary to take into account that the rainwater runoff is wastewater and infiltration facilities are wastewater treatment equipment, so the soil and substances in these facilities are part of the wastewater treatment equipment. The quality of rainwater runoff respectively its composition, mainly affects the contact of rainwater with catchment surfaces. Organic and inorganic composition of rainwater, therefore, depends on the catchment surfaces, local conditions and substances and materials located on the catchment surfaces. The objective 
is permanent protection of soil and groundwater, must be therefore ensured sustainable natural function of the soil and to avoid contamination of groundwater.

Measurements of qualitative parameters ( $\mathrm{pH}$ and conductivity) by multiparameter water sensor started at the end of 2011. Multiparameter water sensor is situated at measurement flume. $\mathrm{pH}$ and conductivity values are being measured continually.

According to (NV SR) No. 269/2010 Z. z., pH values should range from 6 to 8.5[9]. Box-Plot graph on Figure 11 depicts $\mathrm{pH}$ values of rainwater from PK6 building during 2012. Figure 11 shows that the average value of $\mathrm{pH}$ varies each month. In June and October $\mathrm{pH}$ values are below the limit that means that rainwater runoff is acid.

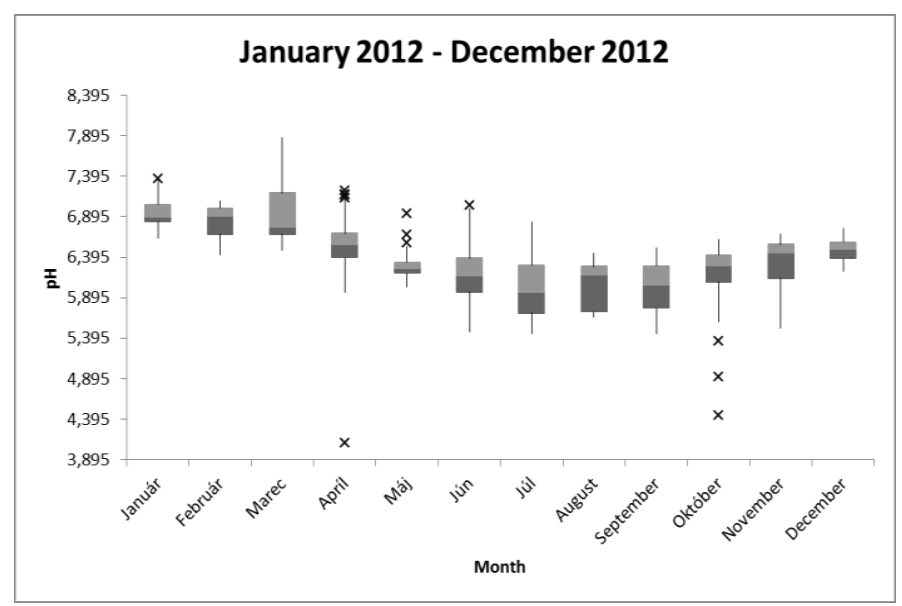

Fig. 11. pH values of rainwater collected from the PK6 building during 2012

Another indicator of the quality of water collected from PK6 building is conductivity. Conductivity, like $\mathrm{pH}$ values, is also measured continually using a multiparameter sensor (figure 12). 


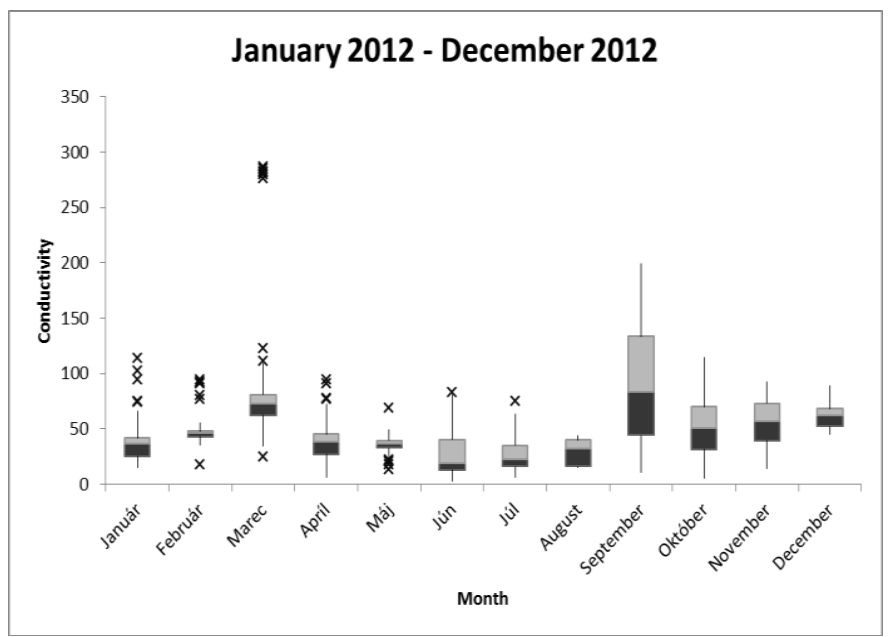

Fig. 12. Conductivity values of rainwater from the PK6 building during 2012

Conductivity means for approximate degree of concentration of electrolytes in water. Conductivity limit for drinking water, according to (NV SR) No. 269/2010 Z. z., equals $100 \mathrm{mS} / \mathrm{m}$ which is about $1000 \mathrm{mg} / \mathrm{l}$ [9]. However, optimally, drinking water should contain less soluble compounds, only about 200-400 mg/l (about 25-50 mS/m).

Conductivity values of rainwater during 2012 are shown in the Box-Plot graph on Figure 12. From the graph we can see that the average value for each month varies, but in most months it is optimal. During periods of rainfall the limit was exceeded, however, conductivity was mostly of the standard value and sometimes even optimal. The only exception was the month of September where the limit was exceeded [2].

\section{Conclusion}

It is always necessary to consider from the view of local conditions about suitability of rainwater infiltration solutions. Therefore, in each case, it is to be considered carefully, which drainage concept in combination with the percolation of precipitation is ecologically sensible, technically possible and economically justifiable [1]. As resulting not only from the overall measured data during the research, the total infiltration of rainwater in the infiltration shaft take place at the time of termination of rainfall events, respectively short-time after which represent a high infiltration rate of this shaft given by the coefficient of infiltration at the bottom of shaft. Therefore, despite the smaller surface for infiltration of infiltration shafts compared to other types of infiltration facilities, the infiltration coefficient of surveyed infiltration shafts $k_{f}=1.10^{-3} \mathrm{~m} / \mathrm{s}$ ensures safe disposal of surface runoff. 
The real measured values of the quality indicators from roof of PK6 building show sufficient quality of rainwater for rainwater harvesting as well as for rainwater infiltration. The most of $\mathrm{pH}$ and conductivity data show similar quality as is required on drinking water.

\section{Acknowledgement}

The work was supported from the VEGA 1/0450/12 Energy balance research on rainwater management in the cities of the future and International Visegrad Fund's, Strategic Grant No. 31210009- "Sustainable Rainwater Management in the V4 Countries".

\section{References}

[1] Standard DWA-A 138E, (2005), Planning, Construction and Operation of Facilities for the Percolation of Precipitation Water.

[2] ČSN 759010 - Vsakovací zařízení srážkových vod 2012

[3] Vrána, J. (2010), Dimenzování vsakovacích zařízení v ČR. In Sanhyga, s. 29-36, Piešt’any.

[4] Žabička, Z.: Technická řešení vsakovacích zařízení. In Sanhyga, s. 17-28, Pieštany, 2010, ISBN 978-80-89216-35-2

[5] Markovič G, Vranayová, Z. - Infiltration as a way of surface water drainage, Košice: TU - 2013. - 137 s.. - ISBN 978-80-553-1541-6.

[6] Slys, D. Potential of rainwater utilization in residential housing in Poland, Water and environment journal Volume: 23 Issue: 4 Pages: 318-325 Published: DEC 2009

[7] Gaňová, L., Zeleňáková, M., Purcz, P., Kuzevičová, Ž., Hlavatá, H.: A rainfall distribution and their influence on flood generation in the eastern Slovakia. In: Acta Universitatis Agriculturae et Silviculturae Mendelianae Brunensis, vol. 61, no. 6, p. 1645-1652, 2013.

[8] Markovič G., Zeleňáková M., Measurements of quality and quantity of rainwater runoff from roof in experimental conditions - 2014. In: ICITSEM 2014 : International conference on innovative trends in science, engineering and managment 2014: 12th and 13th February 2014, Dubaj, UAE. - [Bangalore]: Mudranik Technologies, 2014 P. 145-151. - ISBN 978-93-83303-19-9

[9] The government regulation of Slovak Republic (NV SR) no. 269/2010 Z. z. from May 25th 2010 which sets the requirements for optimal state of water

[10] Uhmannová H., Ondrejka Harbuláková V., Zeleňáková M., Dziopak J., Słyś D., Šlezingr M., Smelík L., Rainwater runoff in the landscape. Brno: CERM, 2013, $114 \mathrm{p}$. 


\section{RESEARCH AND EVALUATION OF INFILTRATION SHAFT EFFICIENCY IN REAL CONDITIONS}

\section{S u m m a r y}

The permeability of infiltration zone is an essential qualitative and quantitative prerequisite for infiltration of rainwater. Permeability is represented by a filtration coefficient $\mathrm{k}_{\mathrm{f}}$, which represents the effectiveness of infiltration facilities, respectively ability of subsoil infiltrate incoming rainwater. Therefore, the most important design parameter of the infiltration facilities is to determine the filtration coefficient $\mathrm{k}_{\mathrm{f}}$ on-site. It is therefore necessary that the designer of the infiltration facilities known hydrogeological conditions in the interest area.

The real measured values of the quality indicators from roof of PK6 building show sufficient quality of rainwater for rainwater harvesting as well as for rainwater infiltration. Rainwater quality for rainwater harvesting or rainwater infiltration systems can also be influenced by the choice of roofing material, iits proper operation and maintenance.

Keywords: efficiency, infiltration, rainwater, runoff, shaft, soil

DOI:10.7862/rb.2014.53

Przestano do redakcji: lipiec 2014 r.

Przyjęto do druku: wrzesień 2014 r. 